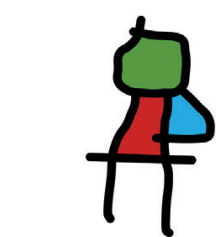

SEICAIP

\section{Allergologia et \\ immunopathologia}

Sociedad Española de Inmunología Clínica,

Alergología y Asma Pediátrica

www.all-imm.com

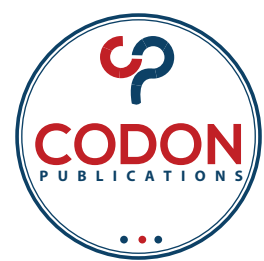

ORIGINAL ARTICLE

OPEN ACCESS (C) (1) (2)

\title{
Outcome of food intake and nutritional status after discontinuation of a cow's-milk-free diet post negative oral food challenge in infants and children
}

\author{
Dayane Pêdra Batista de Fariaa , Marcela Duarte Sillos ${ }^{a}$, \\ Patrícia da Graça Leite Speridião ${ }^{\mathrm{b}}$, Mauro Batista de Morais ${ }^{\mathrm{c*}}$
}

a,cPediatric Gastroenterology Department, Federal University of Sao Paulo, Sao Paulo, Brazil ${ }^{b}$ Department of Health, Education and Society, Institute of Health and Society, Federal University of São Paulo - Baixada Santista Campus, Santos, Brazil

Received 23 June 2021; Accepted 30 September 2021

Available online 1 January 2022

\section{KEYWORDS}

body height;

children;

infant development;

milk hypersensitivity;

nutritional status;

food intake

\begin{abstract}
Objective: To evaluate the outcome of food intake and nutritional status post discontinuation of a cow's-milk-free diet after a negative oral food challenge.

Methods: This was a prospective, uncontrolled study that evaluated food intake and nutritional status of a cohort of 80 infants and children under 5 years of age. Food intake and nutritional status were evaluated on the day of the oral food challenge test and after 30 days. Weight and height were measured on the day of the test and after 30 days.

Results: The mean age of the patients was $18.7 \pm 12.4$ months, and $58.7 \%$ were male. After discontinuation of the elimination diet, the children showed daily intake increases in $(P<0.001)$, protein $(P<0.001)$, carbohydrates $(P=0.042)$, calcium from foods $(P<0.001)$, calcium from foods and supplements $(P<0.001)$, phosphorus $(P<0.001)$, and vitamin $D$ from foods $(P=0.006)$. The Z-scores $(n=76)$ on the day of the oral food challenge test and 30 days after restarting the consumption of cow's milk were as follows: weight-for-age $(P<0.001)$ and height-for-age $(P<0.001)$, respectively.

Conclusion: Cow's milk protein in the diet was associated with increased intake of energy, proteins, carbohydrates, calcium, phosphorus, and vitamin D, in addition to an increase in the Z-scores for weight-for-age and height-for-age.

( 2022 Codon Publications. Published by Codon Publications.
\end{abstract}

*Corresponding author: Mauro Batista de Morais, Pediatric Gastroenterology Department, Federal University of Sao Paulo, Street Pedro de Toledo, 669 - 12th floor, Sao Paulo 04039-032, Brazil. Email address: maurobmorais@gmail.com 


\section{Introduction}

Cow's milk allergy (CMA) is the most common food allergy in infants, ${ }^{1}$ with an estimated prevalence in developed countries ranging from $0.5 \%$ to $3.0 \%$ in the first years of life. ${ }^{2,3}$ In Brazil, an epidemiological study in pediatric gastroenterologist offices revealed that the incidence and prevalence of CMA are $2.2 \%$ and $5.4 \%$, respectively. ${ }^{4}$

To confirm diagnosis of CMA and the development of oral tolerance to cow's milk, a double-blind placebocontrolled food challenge is considered to be the gold standard. ${ }^{3,5-8}$ However, this method is difficult to perform, especially when a reaction is delayed, that is, an allergy can reappear up to 4 weeks from the beginning of reexposure to the allergen.,3,5,6-8 Its application may have greater value in situations in which clinical manifestations are immediate and subjective, and patients may be susceptible to food intake and thus may have sensations not linked to re-exposure to the allergen. ${ }^{8,9}$ In this context, especially in children up to 3 years of age, open food challenge (OFC) is recommended as the first option in clinical practice, ${ }^{1,6,8,10}$ enabling a significant number of patients to be fed a cow's milk protein elimination diet to discontinue the diet..$^{11,12}$

The allergenic protein elimination diet is the treatment for almost all infants and children with CMA. However, the cow's milk elimination diet when improperly used can impact and compromise nutritional status. . $3,6,8^{\text {Taking into }}$ account the higher cost of special formulas for infants with CMA and the difficulties in feeding a diet without cow's milk protein, the ideal situation is to use such a diet for the strictly necessary period. Thus, the performance of the OFC is very important to prove the diagnosis of CMA and to characterize the development of oral tolerance in patients given an elimination diet. It should be highlighted that an exclusion diet is associated with a lower quality of life.,8

Studies conducted in Brazil and other countries have shown that energy and nutrient intake, especially calcium, are lower in children with CMA than in children without food allergies. ${ }^{13-21}$ However, there is little information on the impact of interrupting an elimination diet on food intake and nutritional status. In the literature, only one retrospective study ${ }^{22}$, conducted in Japan, evaluated the growth of 58 children after the discontinuation of a cow'smilk-free diet, which found an increase in height-for-age Z-score. In that study, however, food intake was not evaluated. The authors hypothetized that lower calcium intake could be related to lower values of height-for-age Z-score. To our knowledge, no study has evaluated the changes in food intake provided by the discontinuation of the cow's milk elimination diet.

Therefore, the objective of this study was to evaluate the outcome of food intake and nutritional status after discontinuation of a cow's-milk-free diet post a negative OFC.

\section{Materials and Methods}

\section{Study design}

This was a prospective, uncontrolled study that evaluated food intake and nutritional status of a cohort of infants and children during a cow's milk protein elimination diet and on the 30th day after the discontinuation of such a diet post a negative OFC.

The study was approved by the Research Ethics Committee of UNIFESP under number 0718/10. All the guardians of the children participating in the study signed an informed consent form.

\section{Population sample}

All 130 children under the age of 5 years who were on a cow's milk and dairy elimination diet who underwent the OFC for cow's milk at the São Paulo Hospital of the Federal University of São Paulo, Paulista School of Medicine, between January 2015 and March 2019 were considered for inclusion in the study.

Of these 130 children, 29 (22.3\%) were excluded for having a positive challenge test $(6$ with immediate reactions and 23 with delayed reactions).

Of the 101 that had an oral challenge test negative for cow's milk proteins, 80 (79.2\%) were reassessed after 30 days.

\section{Open food challenge}

The OFC was performed in the morning, with patients fasting, under the supervision of a pediatric gastroenterologist and nutritionist. Before the test, information on the purpose of the test (diagnostic confirmation or assessment of the development of oral tolerance) was provided, and the duration of the cow's milk and dairy elimination diet, type of special substitute formula that had been used, and clinical manifestations that motivated previous possible diagnosis of allergy to cow's milk protein were obtained.

A complete physical examination was performed, and weight and height were measured before the start of the OFC. Next, $1 \mathrm{~mL}$ of cow's milk was administered directly into the oral cavity, avoiding contact with the labial region. After $20 \mathrm{~min}$, if no adverse reaction had occurred, an additional $10 \mathrm{~mL}$ was administered orally. If the patient remained asymptomatic, new volumes of milk were administered twice orally in increasing volumes every $20 \mathrm{~min}$ $(20 \mathrm{~mL}, 40 \mathrm{~mL}$, and $80 \mathrm{~mL}$ ) until the total volume of milk ingested reached $151 \mathrm{~mL} .{ }^{8,11}$

If the patient remained asymptomatic for another hour (total of $2 \mathrm{~h}$ and 30 min after the beginning of oral exposure to cow's milk), a new physical examination was performed. If there were no abnormalities, the patient was discharged for outpatient follow-up. After discharge, a diet with cow's milk and dairy products was followed, replacing cow's milk protein-free formula by infant formula with cow's milk protein or cow's milk. For children with acceptance difficulties, it was recommended that the infant formula or cow's milk be mixed with the formula that had been previously used, ensuring a minimum intake of $150 \mathrm{~mL}$ of cow's milk protein preparation per day.

Patients were instructed to call if there were any symptoms. When necessary, the patient returned for an in-person medical evaluation. If there was no reaction, the 
patient returned for clinical and anthropometric evaluations and to perform a new food survey 30 days after the start of the challenge test.

If the child remained asymptomatic at the end of 30 days, that is, without signs or symptoms consistent with CMA, the OFC was considered negative. ${ }^{1,23}$

When the patient presented clinical manifestations resulting from the ingestion of cow's milk protein, the test was considered positive. ${ }^{1,3,6,7,8}$ Reactions that occurred up to $2 \mathrm{~h}$ after the beginning of re-exposure to cow's milk were considered immediate. The reactions that occurred later, until the 30th day, were considered delayed. ${ }^{1,24}$

\section{Assessment of nutritional status}

Weight and height were measured and classified based on standards provided by the World Health Organization, ${ }^{25}$ on the day of the OFC and on outpatient follow-up after 30 days. The classification of nutritional status was based on anthropometric indices, weight-for-age (W/A), weight-forheight $(W / H)$, height-for-age $(H / A)$, and body mass indexfor-age $(\mathrm{BMI} / \mathrm{A})$, with the aid of Anthro software, version 3.2.2. Weight and height measurements on the 30th day were performed without knowledge of the measurements obtained on the day of the OFC.

\section{Food intake}

Food intake was assessed by means of a 24-h recall survey on the day of the OFC and 30 days after lifting the restriction of cow's milk in the diet. The 24 -h recall was performed by a single nutritionist in both evaluations in accordance with the recommendations. ${ }^{26,27}$ To help quantify the size of the portions, a photographic album of food portions was used. If the children were taking dietary supplements, parents were asked to supply the basic supplement information, including the brand name, manufacturer, and daily dosage, to estimate nutrient intake through the dietary supplements. For the calculation of energy, protein, lipids, carbohydrates, calcium, phosphorus, iron, and vitamins $A, C$ and $D$, the software Avanutri online $\AA^{28}$ (Rio de Janeiro, Brazil) was used. The food intake data obtained in the two evaluations were interpreted based on dietary reference intakes (DRIs). ${ }^{29,30}$

\section{Statistical analysis}

Statistical analysis was performed using SigmaStat software version 3.5 (SPSS Inc., Chicago, USA). ${ }^{31}$ Numerical variables were presented as absolute number and percentage. All results of statistical analyses are expressed as mean and standard deviation or as median and 25th and 75th percentiles. The paired Student's t test or the non-parametric Wilcoxon test were used for intragroup comparisons (at OFC and 30 days after the test). The McNemar test was used to verify whether there was a change in the adequacy or inadequacy ratio in food intake in relation to DRIs. The tests used are presented together with the results. The level for rejection of the null hypothesis was set at $<0.05$ or $5 \%$.

\section{Results}

\section{Demographic and clinical characteristics}

Table 1 shows the clinical and demographic characteristics of the 80 children who had a negative OFC for cow's milk and who were reassessed after 30 days. Before the challenge test, most patients received an extensively hydrolyzed formula or amino acid formula. The duration of the cow's milk and dairy elimination diet was greater than 24 weeks for most patients.

Regarding the clinical manifestations that motivated the diagnostic hypothesis of CMA, gastrointestinal manifestations predominated in $95.0 \%(76 / 80)$, and cutaneous manifestations predominated in $13.7 \%(11 / 80)$ of the patients. Respiratory manifestations occurred less frequently, that is, in $10.0 \%(8 / 80)$. In $15 \%(12 / 80)$ of the children, two or more symptoms or signs were observed, and in $85 \%(68 / 80)$, three or more symptoms or signs were observed.

\section{Food intake}

Table 2 shows the intake of energy and macro- and micronutrients on the day of the OFC and 30 days after consuming a diet without any restrictions. There was a statistically significant increase in energy, protein, and carbohydrate intake. There was no variation in lipid intake. Regarding micronutrient intake, there was an increase in calcium, phosphorus, and vitamin $D$ via food. The intake of iron, vitamin $A$, and vitamin $D$ in food did not vary 30 days after

Table 1 Demographic and clinical characteristics of children with a negative oral food challenge for cow's milk.

\begin{tabular}{lrr}
\hline Variable & $\mathrm{n}=80$ & $\%$ \\
\hline Gender & & \\
$\quad$ Males & 47 & 58.7 \\
$\quad$ Female & 33 & 41.3 \\
Age (months) & & \\
0-6 & 4 & 5.0 \\
7-12 & 33 & 41.3 \\
13-24 & 27 & 33.7 \\
25-60 & 16 & 20.0 \\
Indication oral food challenge & & \\
Diagnostic & 16 & 20.0 \\
Tolerance & 64 & 80.0 \\
Duration of cow's-milk-free diet (weeks) & & \\
$\quad$ 12 & 5 & 6.3 \\
13-24 & 29 & 36.2 \\
25-47 & 26 & 32.5 \\
$\quad 48$ & 20 & 25.0 \\
Type of cow's milk substitute & & \\
Amino acid-based formula & 31 & 38.7 \\
Extensively hydrolyzed formula & 32 & 40.0 \\
Soy protein-based formula & 8 & 10.0 \\
Soy extract-based beverage/juice & 6 & 7.5 \\
Rice drink & 1 & 1.3 \\
No substitute & 2 & 2.5 \\
\hline & &
\end{tabular}


Table 2 Energy, macronutrient, and micronutrient intake on the day of oral food challenge and after 30 days.

\begin{tabular}{|c|c|c|c|}
\hline Variable & On the day & After 30 days & $P$ \\
\hline Total energy (kcal/day) & $896.7 \pm 246.9$ & $961.9 \pm 227.1$ & $<0.0011$ \\
\hline Protein (g/day) & $35.5 \pm 11.2$ & $41.1 \pm 13.9$ & $<0.001^{1}$ \\
\hline Lipids (g/day) & $28.7 \pm 12.0$ & $29.7 \pm 10.3$ & $0.320^{1}$ \\
\hline Carbohydrate (g/day) & $125.7(103.1 ; 147.5)$ & $130.3(109.1 ; 155.7)$ & $0.042^{2}$ \\
\hline Calcium from foods (mg/day) & $495.2(332.7 ; 587.2)$ & $712.6(513.5 ; 928.3)$ & $<0.001^{2}$ \\
\hline Calcium from foods and supplements (mg/day) ${ }^{a}$ & $516.2(351.8 ; 608.5)$ & $722.9(557.3 ; 940.2)$ & $<0.001^{2}$ \\
\hline Phosphorus (mg/day) & $463.1(357.1 ; 557.7)$ & $680.5(489.1 ; 786.9)$ & $<0.001^{2}$ \\
\hline Iron from foods (mg/day) & $10.9(7.7 ; 12.6)$ & $9.3(5.9 ; 11.8)$ & $0.476^{2}$ \\
\hline Iron from foods + supplements $(\mathrm{mg} / \mathrm{day})^{\mathrm{b}}$ & $13.5(10.2 ; 22.9)$ & $12.7(9.1 ; 21.5)$ & $0.392^{2}$ \\
\hline Vitamin A from foods ( $\mu \mathrm{g} /$ day) & $823.4 \pm 505.4$ & $895.0 \pm 584.5$ & 0.344 \\
\hline Vitamin A from foods + supplements $(\mu \mathrm{g} / \mathrm{day})^{\mathrm{c}}$ & $1217.1 \pm 613.4$ & $1287.0 \pm 715.4$ & $0.360^{1}$ \\
\hline Vitamin C from foods(mg/day) & $103.2(72.0 ; 151.5)$ & $136.4(71.5 ; 178.1)$ & $0.100^{2}$ \\
\hline Vitamin C from foods + supplements (mg/day) ${ }^{d}$ & $109.9(76.5 ; 168.6)$ & $139.9(81.8 ; 186.0)$ & $0.104^{2}$ \\
\hline Vitamin D from foods (mg/day) & $7.6(4.1 ; 10.8)$ & $8.8(5.0 ; 11.8)$ & $0.006^{2}$ \\
\hline Vitamin D from foods + supplements (mg/day) ${ }^{e}$ & $15.6(7.2 ; 21.1)$ & $15.4(8.0 ; 23.1)$ & $0.063^{2}$ \\
\hline
\end{tabular}

${ }^{1}$ Paired t-test. ${ }^{2}$ Wilcoxon test.

aFive children received calcium supplementation on the day of the oral food challenge and after 30 days (median $=400.0 \mathrm{mg}, 25$ th and 75th percentiles: $212.0 ; 500.0$ ). ${ }^{b} 40$ children received iron supplementation on the day of the oral food challenge (median $=10.0 \mathrm{mg}$, 25th and 75th percentiles: 9.0; 23.5), and 36 children received it after 30 days (median = 10.0, 25th and 75th percentiles: 8.5; 22.5). "46 children received vitamin A supplementation on the day of the oral food challenge (median $=750.0 \mu \mathrm{g}, 25$ th and 75th percentiles: 750.0; 750.0), and 44 children received it after 30 days (median $=750.0 \mu \mathrm{g}$, 25th and 75th percentiles: 750.0; 750.0). ${ }^{\text {NNine }}$ children received vitamin C supplementation on the day of the oral food challenge and after 30 days (median $40.0 \mathrm{mg}$, 25th and 75th percentiles: $30.0 ; 110.0)$. ${ }^{e} 47$ children received vitamin $D$ supplementation on the day of the oral food challenge (median $=12.5 \mathrm{mg}, 25 \mathrm{th}$ and 75th percentiles: $12.5 ; 12.5$ ), and 45 children received it after 30 days (median $=12.5 \mathrm{mg}$, 25th and 75 th percentiles: $12.5 ; 12.5$ ).

the test. The mineral and vitamin supplements were maintained at the same dose after the OFC.

\section{Adequate intake of macro- and micronutrients relative to DRIs}

Table 3 shows the frequency (number and percentages) of children who had adequate intake of macro- and micronutrients relative to DRIs before and after the OFC. There was a statistically significant increase in the proportion of children with adequate calcium and phosphorus intake.

\section{Nutritional status}

Table 4 provides the Z-scores for weight-for-age, weight-forheight, height-for-age, and BMI-for-age on the day of the oral food challenge and after 30 days. There was a statistically significant increase in the weight-for-age and heightfor-age Z-scores. The weight-for-height and BMI-for-age Z-scores showed no statistically significant variation.

\section{Discussion}

The increase in children's food intake after discontinuing the cow's milk protein-free diet showed that the return to the usual diet, that is, without restrictions, was associated with an improvement in the children's food intake, including the proportion of adequate intake of calcium in relation to DRIs. It is likely that the increase in food intake is related to the possibility of using greater variety of foods in the diet, especially cow's milk and other foods containing cow's milk proteins. There was also an increase in weight-for-age and height-for-age Z-scores.

These results reinforce the concept that an elimination diet should be used only for the period that is strictly necessary. Therefore, it is essential to perform OFC not only to confirm the diagnosis of CMA but also to characterize the development of oral tolerance. In our sample, of the 130 children who underwent the oral challenge test, 101 (77.6\%) had a negative OFC, that is, they changed to a diet without any restrictions for cow's milk and dairy products. A similar rate of negativity for the oral challenge test was observed in a previous study. ${ }^{11}$ Conversely, other studies conducted in Recife (Brazil) ${ }^{12}$ and the Netherlands ${ }^{32}$ found a lower positivity rate of approximately $50.0 \%$. This difference was likely observed because in our sample, the oral challenge test was performed predominantly for the study of oral tolerance, while in the aforementioned studies, the challenge food was used predominantly to establish the diagnosis of CMA. ${ }^{11,32}$ In other words, the expectation of positivity, in general, is higher when the test is for diagnostic purposes rather than for oral tolerance assessments.

According to international consensus, it is important to systematically monitor the development of oral tolerance by children with food allergies. Therefore, OFC should be performed every 6-12 months whenever possible to identify oral food tolerance. ${ }^{1,3,8}$

Regarding the use of special formulas, our study showed that extensively hydrolyzed formula and amino acid formula were the most commonly used. Notably, a recent study in Brazil $^{33}$ showed that special formulas (based on extensively hydrolyzed protein and amino acids) represent an important source of nutrients for infants on 
Table 3 Frequency (number and percentages) of children with adequate and inadequate energy, protein, carbohydrate, lipids, phosphorus, calcium, iron, and vitamins A, C, and D intake through food, based on dietary reference intakes, on the day of the oral food challenge and after 30 days

\begin{tabular}{|c|c|c|c|c|c|c|c|c|}
\hline & & \multicolumn{7}{|c|}{ After 30 days } \\
\hline & & \multicolumn{2}{|c|}{ Inadequate } & \multicolumn{2}{|c|}{ Adequate } & \multicolumn{2}{|c|}{ Total } & \multirow[b]{2}{*}{$\mathrm{P}^{1}$} \\
\hline & & $\mathrm{n}$ & $\%$ & $\mathrm{n}$ & $\%$ & $\mathrm{n}$ & $\%$ & \\
\hline \multicolumn{9}{|l|}{ Energy } \\
\hline \multirow[t]{3}{*}{ On the day } & Inadequate & 26 & (32.5) & 12 & (15.0) & 38 & $(47.5)$ & 0.146 \\
\hline & Adequate & 5 & $(6.3)$ & 37 & (46.2) & 42 & (52.5) & \\
\hline & Total & 31 & $(38.8)$ & 49 & $(61.2)$ & 80 & $(100.0)$ & \\
\hline \multicolumn{9}{|l|}{ Protein } \\
\hline \multirow[t]{3}{*}{ On the day } & Inadequate & 0 & $(0.0)$ & 4 & $(5.0)$ & 4 & $(5.0)$ & 0.134 \\
\hline & Adequate & 0 & $(0.0)$ & 76 & (95.0) & 76 & $(95.0)$ & \\
\hline & Total & 0 & $(0.0)$ & 80 & $(100.0)$ & 80 & $(100.0)$ & \\
\hline \multicolumn{9}{|c|}{ Carbohydrate } \\
\hline \multirow[t]{3}{*}{ On the day } & Inadequate & 13 & $(16.3)$ & 15 & (18.7) & 28 & $(35.0)$ & 0.136 \\
\hline & Adequate & 7 & $(8.7)$ & 45 & (56.3) & 52 & $(65.0)$ & \\
\hline & Total & 20 & $(25.0)$ & 60 & (75.0) & 80 & $(100.0)$ & \\
\hline \multicolumn{9}{|l|}{ Lipids } \\
\hline \multirow[t]{3}{*}{ On the day } & Inadequate & 22 & (27.5) & 14 & (17.5) & 36 & $(45.0)$ & 0.540 \\
\hline & Adequate & 10 & (12.5) & 34 & (42.5) & 44 & $(55.0)$ & \\
\hline & Total & 32 & $(40.0)$ & 48 & $(60.0)$ & 80 & $(100.0)$ & \\
\hline \multicolumn{9}{|l|}{ Phosphorus } \\
\hline \multirow[t]{3}{*}{ On the day } & Inadequate & 7 & $(8.7)$ & 14 & (17.5) & 21 & $(26.3)$ & 0.022 \\
\hline & Adequate & 4 & $(5.0)$ & 55 & $(68.8)$ & 59 & (73.7) & \\
\hline & Total & 11 & (13.7) & 69 & (86.3) & 80 & $(100.0)$ & \\
\hline \multicolumn{9}{|l|}{ Calcium } \\
\hline \multirow[t]{3}{*}{ On the day } & Inadequate & 23 & $(28.7)$ & 22 & $(27.5)$ & 45 & (56.3) & $<0.001$ \\
\hline & Adequate & 4 & $(5.0)$ & 31 & $(38.8)$ & 35 & $(43.7)$ & \\
\hline & Total & 27 & (33.7) & 53 & $(66.3)$ & 80 & $(100.0)$ & \\
\hline Calcium $+\mathbf{s}$ & ments & & & & & & & \\
\hline On the day & Inadequate & 22 & (27.5) & 18 & (22.5) & 40 & $(50.0)$ & $<0.012$ \\
\hline & Adequate & 5 & $(6.2)$ & 35 & $(43.8)$ & 40 & $(50.0)$ & \\
\hline & Total & 27 & (33.7) & 53 & $(66.3)$ & 80 & $(100.0)$ & \\
\hline Iron & & & & & & & & \\
\hline On the day & Inadequate & 16 & $(20.0)$ & 9 & (11.3) & 25 & (31.3) & 0.170 \\
\hline & Adequate & 17 & $(21.2)$ & 38 & (47.5) & 55 & $(68.7)$ & \\
\hline & Total & 33 & $(41.2)$ & 47 & (58.8) & 80 & $(100.0)$ & \\
\hline Iron + supp & & & & & & & & \\
\hline On the day & Inadequate & 4 & $(5.0)$ & 4 & $(5.0)$ & 8 & $(10.0)$ & 0.121 \\
\hline & Adequate & 11 & (13.8) & 61 & (76.2) & 72 & $(90.0)$ & \\
\hline & Total & 15 & (18.8) & 65 & $(81.2)$ & 80 & (100.0) & \\
\hline Vitamin A & & & & & & & & \\
\hline On the day & Inadequate & 7 & $(8.7)$ & 11 & (13.8) & 18 & $(22.5)$ & 0.831 \\
\hline & Adequate & 11 & (13.8) & 51 & (63.7) & 62 & (77.5) & \\
\hline & Total & 18 & (22.5) & 55 & (77.5) & 80 & $(100.0)$ & \\
\hline Vitamin A + & ements & & & & & & & \\
\hline On the day & Inadequate & 4 & $(5.0)$ & 6 & (7.5) & 10 & (12.5) & 1.000 \\
\hline & Adequate & 5 & $(6.3)$ & 65 & $(81.2)$ & 70 & (87.5) & \\
\hline & Total & 9 & (11.3) & 71 & (88.7) & 80 & $(100.0)$ & \\
\hline Vitamin C & & & & & & & & \\
\hline On the day & Inadequate & 5 & $(6.2)$ & 3 & (3.8) & 8 & $(10.0)$ & 0.505 \\
\hline & Adequate & 6 & (7.5) & 66 & (82.5) & 72 & $(90.0)$ & \\
\hline & Total & 11 & (13.7) & 69 & $(86.3)$ & 80 & $(100.0)$ & \\
\hline Vitamin C + & ements & & & & & & & \\
\hline On the day & Inadequate & 3 & (3.8) & 3 & (3.8) & 6 & (7.5) & 0.343 \\
\hline & Adequate & 7 & $(8.7)$ & 67 & (83.7) & 74 & $(92.5)$ & \\
\hline & Total & 10 & $(12.5)$ & 70 & (87.5) & 80 & $(100.0)$ & \\
\hline
\end{tabular}


Table 3 (Continued)

\begin{tabular}{|c|c|c|c|c|c|c|c|c|}
\hline & & \multicolumn{7}{|c|}{ After 30 days } \\
\hline & & \multicolumn{2}{|c|}{ Inadequate } & \multicolumn{2}{|c|}{ Adequate } & \multicolumn{2}{|c|}{ Total } & \multirow[b]{2}{*}{$\mathrm{P}^{1}$} \\
\hline & & $\mathrm{n}$ & $\%$ & $\mathrm{n}$ & $\%$ & $\mathrm{n}$ & $\%$ & \\
\hline \multicolumn{9}{|l|}{ Vitamin D } \\
\hline \multirow[t]{3}{*}{ On the day } & Inadequate & 44 & $(55.0)$ & 12 & $(15.0)$ & 56 & $(70.0)$ & 0.080 \\
\hline & Adequate & 5 & $(6.3)$ & 19 & $(23.7)$ & 24 & $(30.0)$ & \\
\hline & Total & 49 & $(61.3)$ & 31 & $(38.7)$ & 80 & $(100.0)$ & \\
\hline \multicolumn{9}{|c|}{ Vitamin D + supplements } \\
\hline \multirow[t]{3}{*}{ On the day } & Inadequate & 28 & $(35.0)$ & 8 & $(10.0)$ & 36 & $(45.0)$ & 1.000 \\
\hline & Adequate & 7 & $(8.7)$ & 37 & $(46.3)$ & 44 & $(55.0)$ & \\
\hline & Total & 35 & (43.7) & 45 & (56.3) & 80 & $(100.0)$ & \\
\hline
\end{tabular}

Table 4 Z-scores for weight and height and frequency of the anthropometric deficit on the day of oral food challenge and after 30 days.

\begin{tabular}{|c|c|c|c|}
\hline Variable & $\begin{array}{l}\text { On the day } \\
\quad(n=76)\end{array}$ & $\begin{array}{c}\text { After } 30 \\
\text { days } \\
(\mathrm{n}=76)\end{array}$ & $\mathrm{P}$ \\
\hline \multicolumn{4}{|l|}{ Z-scores } \\
\hline Weight-for-age & $\begin{array}{c}-0.6(-1.7 ; \\
0.0)\end{array}$ & $\begin{array}{c}-0.4(-1.4 \\
0.2)\end{array}$ & $<0.001^{1}$ \\
\hline Weight-for-height & $-0.1 \pm 1.1$ & $-0.1 \pm 1.0$ & $0.793^{2}$ \\
\hline Height-for-age & $-1.1 \pm 1.6$ & $-0.8 \pm 1.4$ & $<0.001^{2}$ \\
\hline $\begin{array}{l}\text { Body mass } \\
\text { index-for-age }\end{array}$ & $-0.0 \pm 1.1$ & $-0.0 \pm 0.9$ & $0.961^{2}$ \\
\hline \multicolumn{4}{|c|}{ Anthropometric deficit (Z-scores $<-2.0$ ) } \\
\hline Weight-for-age & $12(15.8 \%)$ & $9(11.8 \%)$ & $0.248^{3}$ \\
\hline Height-for-age & $18(23.7 \%)$ & 14 (18.4\%) & $0.182^{3}$ \\
\hline Weight-for-height & $3(3.9)$ & $3(4.0 \%)$ & $0.480^{3}$ \\
\hline $\begin{array}{l}\text { Body mass } \\
\text { index-for-age }\end{array}$ & $2(2.6 \%)$ & $1(1.3 \%)$ & $1.000^{3}$ \\
\hline
\end{tabular}

${ }^{1}$ Wilcoxon test; ${ }^{2}$ Paired $t$ test; ${ }^{3} \mathrm{McNemar}$ test.

an elimination diet even after the introduction of complementary feeding.

Our study showed relevant information regarding calcium intake. Although most patients were being monitored in a multidisciplinary unit, a portion of patients $(56.3 \%)$ had inadequate calcium intake, even when receiving supplementation. A study ${ }^{17}$ conducted in Italy showed that nutrition counseling was accompanied by a higher intake of energy, carbohydrates, proteins, and calcium. Nutritional monitoring is important during the cow's milk elimination diet. Counseling by a pediatrician and dietician experienced in pediatric nutrition is highly recommended to ensure adequate nutrient intake and monitor the nutritional status of patients. ${ }^{1,8,17,34}$ In this study, the impact of nutritional guidance was not evaluated. Previously, it was observed in Brazil that there may be limitations in the understanding of patients regarding nutritional guidelines and their ability to implement dietary recommendations. ${ }^{35}$ Based on these findings, the care protocols and guideline adherence protocols should be reassessed.
Our study showed that discontinuation of the cow's milk protein elimination diet was accompanied by higher calcium intake and a higher proportion of children with an adequate diet relative to DRIs for most macro- and micronutrients, with the maintenance of the same doses of mineral and vitamin supplements. Our findings before discontinuing the cow's milk protein-free diet are in agreement with previous studies ${ }^{13-21}$ that found nutrient deficits, especially for energy, proteins, lipids, and calcium, in the diet of children with CMA relative to the DRIs and relative to the food intake of healthy children. Thus, the dietary restriction required to control CMA can negatively impact food intake and impair child growth and development. .11,13,18-22 $^{2}$

In addition to the changes in food intake, there was an impact on anthropometric parameters, that is, 30 days after discontinuation of a diet free of cow's milk and dairy products, there were fewer children with Z-scores $<-2.0$ standard deviations for weight-for-age, height-for-age, and BMI-for-age; however, the variation was not statistically significant. On the other hand, there was a statistically significant increase in the individual weight-for-age and height-for-age Z-scores. Importantly, on the day of the OFC, the predominant anthropometric deficit was height-for-age, found in $23.7 \%$ of children, similar to that observed in a previous study conducted in Brazil. ${ }^{4}$ Other studies in Brazil ${ }^{13,16}$ and in other countries ${ }^{17,18,19,36,37}$ reported lower height-for-age, weight-for-age and Weight-for-height Z-scores for children on a cow's milk protein elimination diet than for healthy children.

As already mentioned, only one study in the literature has evaluated the impact of diet discontinuation on growth. ${ }^{22}$ Only the height measurements of 58 children who had a negative OFC and another height measurement approximately 1 year after discontinuing the cow's milk protein elimination diet were retrospectively evaluated. The authors observed, relative to the Japanese growth curve, an increase in height-for-age Z-scores from $-0.28 \pm 0.96$, at the time of diet discontinuation, to $-0.12 \pm 1.07,1$ year later $(P=0.017)$. In our study, there was an increase not only in height-for-age but also in weight-for-age observed in a period of only 30 days. Despite these variations in the individual Z-scores, there was no reduction in the percentage of children with anthropometric deficits, that is, with Z-scores less than -2.0 standard deviations. It is interesting 
to note that in the Japanese study, although the authors do not provide information on food intake, the possible increase in calcium intake was considered the most likely explanation for the improvement in height-for-age Z-score. In our study, there was an increase in both calcium intake and a reduction in the proportion of children with intake below the DRIs. There are many factors associated with the growth and development of children with CMA, such as food intake, inflammation during the allergic process, and nutrient bioavailability. However, this issue should be evaluated in future studies.

The present study has some limitations, such as the lack of a control group. However, it would not be ethical to keep children with a negative OFC on an elimination diet. In addition, the 30-day follow-up period can be considered short; however, it was sufficient to show statistically significant variations not only in feeding but also in anthropometric parameters.

\section{Conclusion}

Our study showed that after a negative OFC, the inclusion of cow's milk and dairy products in the diet was associated with an increase in the intake of energy, proteins, carbohydrates, calcium, phosphorus, and vitamin $D$ and increased weight-for-age and height-for-age Z-scores. These findings are an incentive to perform OFC in order to discontinue elimination diets at the most appropiate time.

\section{Acknowledgments}

This study was supported by National Council for Scientific and Technological Development (Conselho Nacional de Desenvolvimento Científico e Tecnológico - CNPq).

\section{Conflict of Interest}

The authors declare no potential conflicts of interest with respect to research, authorship, and/or publication of this article.

\section{References}

1. Koletzko S, Niggemann B, Arato A, Dias JA, Heuschkel R, Husby $S$, et al. Diagnostic approach and management of cow's-milk protein allergy in infants and children: ESPGHAN GI Committee practical guidelines. J Pediatr Gastroenterol Nutr. 2012;55:221-9. http://dx.doi.org/10.1097/ MPG.0b013e31825c9482

2. Flom JD, Sicherer SH. Epidemiology of cow's milk allergy. Nutrients. 2019;11:1051. http://dx.doi.org/10.3390/nu11051051

3. Boyce JA, Assa'a A, Burks AW, Jones SM, Sampson HA, Wood RA, et al. Guidelines for the diagnosis and management of food allergy in the United States: Summary of the NIAIDsponsored expert panel report. Nutrition. 2011;27:253-67. http://dx.doi.org/10.1016/j.nut.2010.12.001

4. Vieira MC, Morais MB, Spolidoro JV, Toporovski MS, Cardoso AL, Araujo GT, et al. A survey on clinical presentation and nutritional status of infants with suspected cow' milk allergy. BMC Pediatr. 2010;10:25. http://dx.doi.org/10.1186/1471-2431-10-25
5. Solé D, Silva L, Rodrigues Cocco R, Targa Ferreira C, Oselka Sarni R, Camargo Oliveira L, et al. Sociedade Brasileira de Pediatria e Associação Brasileira de Alergia e Imunologia. Consenso Brasil Sobre Alergia Alimentar. 2018;2:7-38. http:// dx.doi.org/10.5935/2526-5393.20180004

6. Luyt D, Ball H, Makwana N, Green MR, Bravin K, Nasser SM, et al. Standards of Care Committee (SOCC) of the British Society for Allergy and Clinical Immunology. BSACl guideline for the diagnosis and management of cow's milk allergy. Clin Exp Allergy. 2014;44:642-72. http://dx.doi.org/10.1111/ cea.12302

7. Muraro A, Werfel T, Hoffmann-Sommergruber K, Roberts $G$, Beyer K, Bindslev-Jensen C, et al. EAACl food allergy and anaphylaxis guidelines: Diagnosis and management of food allergy. Allergy. 2014;69:1008-25. http://dx.doi.org/10.1111/all.12429.

8. Solé D, Silva L, Rodrigues Cocco R, Targa Ferreira C, Oselka Sarni R, Camargo Oliveira L, et al. Sociedade Brasileira de Pediatria e Associação Brasileira de Alergia e Imunologia. Consenso Brasil Sobre Alergia Alimentar. 2018;2:39-82. http:// dxdoi.org/10.5935/2526-5393.20180004

9. Noimark L, Gardner J, Warner JO. Parents' attitudes when purchasing products for children with nut allergy: A UK perspective. Pediatr Allergy Immunol. 2009;20:500-4. http://dx. doi.org/10.1111/j.1399-3038.2008.00796.x

10. Bindslev-Jensen C, Ballmer-Weber BK, Bengtsson U, Blanco C, Ebner C, Hourihane J, et al. Standardization of double-blind, placebocontrolled food challenges in patients with immediate reactions to foods. Allergy. 2004;59:690-7. http://dx.doi. org/10.1111/j.1398-9995.2004.00466.x

11. Correa FF, Vieira MC, Yamamoto DR, Speridião PGL, Morais MB. Open challenge for the diagnosis of cow's milk protein allergy. J Pediatr (Rio J). 2010;86:163-6. http://dx.doi.org/10.2223/ JPED.1967

12. Lins MG, Horowitz MR, Silva GA, Motta ME. Oral food challenge test to confirm the diagnosis of cow's milk allergy. J Pediatr (Rio J). 2010;86:285-9. http://dx.doi.org/10.2223/JPED.2011

13. Medeiros LCS, Speridião PGL, Sdepanian VL, FagundesNeto $U$, Morais MB. Nutrient intake and nutritional status of children following a diet free from cow's milk and cow's milk by-products. J Pediatr. 2004;80:363-70. http://dx.doi. org/10.2223/1220

14. Tiainen JM, Nuutinen OM, Kalavainen MP. Diet and nutritional diet and nutritional status in children with cow's milk allergy. Eur J Clin Nutr. 1995;49:605-12.

15. Henriksen C, Eggesbo M, Halvorsen R, Botten G. Nutrient intake among two- year-old children on cows' milkrestricted diets. Acta Paediatr. 2000;89:272-8. http://dx.doi. org/10.1111/j.1651-2227.2000.tb01328.x

16. Boaventura RM, Mendonça RB, Fonseca RA, Mallozi M, Souza FS, Sarni ROS. Nutritional status and food intake of children with cow's milk allergy. Allergol Immunopathol (Madr). 2019;47:544-50. http://dx.doi.org/10.1016/j.aller.2019.03.003

17. Berni Canani R, Leone L, D’Auria E, Riva E, Nocerino R, Ruotolo $S$, et al. The effects of dietary counseling on children with food allergy: A prospective, multicenter intervention study. J Acad Nutr Diet. 2014;114:1432-9. http://dx.doi. org/10.1016/j.jand.2014.03.018

18. Isolauri E, Sütas $Y$, Salo MK, Isosomppi R, Kaila M. Elimination diet in cow's milk allergy: Risk for impaired growth in young children. J Pediatr. 1998;132:1004-9. http://dx.doi. org/10.1016/S0022-3476(98)70399-3

19. Robbins KA, Wood RA, Keet CA. Milk allergy is associated with decreased growth in U.S. children. J Allergy Clin Immunol. 2014;134:1466-8. http://dx.doi.org/10.1016/j.jaci.2014.08.037

20. Mehta H, Ramesh M, Feuille E, Groetch M, Wang J. Growth comparison in children with and without food allergies in 2 different demographic populations. J Pediatr. 2014;165:842-8. http://dx.doi.org/10.1016/j.jpeds.2014.06.003 
21. Christie L, Hine RJ, Parker JG, Burks W. Food allergies in children affect nutrient intake and growth. J Am Diet Assoc. 2002;102:1648-51. http://dx.doi.org/10.1016/ S0002-8223(02)90351-2

22. Yanagida N, Minoura T, Kitaoka S. Does terminating the avoidance of cow's milk lead to growth in height. Int Arch Allergy Immunol. 2015;168:56-60. http://dx.doi. org/10.1159/000441499

23. Fiocchi A, Brozek J, Schünemann H, Bahna SL, von Berg A, Beyer K, et al. World Allergy Organization (WAO) diagnosis and rationale for action against cow's milk allergy (DRACMA) guidelines. Pediatr Allergy Immunol. 2010;21:1-125. http://dx. doi.org/10.1111/j.1399-3038.2010.01068.x

24. Niggemann B. When is an oral food challenge positive? Allergy. 2010;65:2-6. http://dx.doi.org/10.1111/j.1398-9995. 2009.02170.x

25. Organización Mundial de la Salud. Interpretando los Indicadoresde Crecimiento Interpretando los Indicadores. Curso Capacitsobre la Evaluación del Crecim del Nîno. Ginebra: OMS; 2008.

26. Fisberg RM, Marchioni DML, Colucci ACA. Avaliação do consumo alimentar e da ingestão de nutrientes na prática clínica. Arq Bras Endocrinol Metab. 2009;53:616-24. http://dx.doi. org/10.1590/S0004-27302009000500014

27. Thompson F, Byers T. Dietary assessment resource manual. J Nutr. 1994;124:2245S-2317S. http://dx.doi.org/10.1093/ jn/124.suppl_11.2245s

28. AVANUTRI $\circledast$ on-line. Avanutri \& Nutrição Serviços e Informática Ltda Me. Disponível em <http://www.avanutrionline.com/ principal.asp>.
29. Institute of Medicine (IOM). Dietary reference intakes: The essential guide to nutrient requirements. Washington, DC, USA: National Academies Press; 2006. p. 543.

30. Institute of Medicine. Dietary reference intakes for calcium and vitamin D. Washington, DC: National Academies Press; 2011. p.349-63.

31. Software Sigma Stat versão 3.5 (SPSS Inc., Chicago, EUA); 2005

32. Petrus NC, Schoemaker AF, van Hoek MW, Jansen L, Jansenvan der Weide MC, van Aalderen WM, et al. Remaining symptoms in half the children treated for milk allergy. Eur J Pediatr. 2015;174:759-65. http://dx.doi.org/10.1007/s00431-014-2456-6

33. Duarte JF. Práticas de alimentação complementar, ingestão alimentar e classificação do estado nutricional de lactentes em dieta de eliminação das proteínas do leite de vaca. Dissertação [Mestrado em Ciências], Universidade Federal de São Paulo; 2020.

34. Mazzocchi A, Venter C, Maslin K, Agostoni C. The role of nutritional aspects in food allergy: Prevention and management. Nutrients. 2017;9:850. http://dx.doi.org/10.3390/nu9080850

35. Weber TK, Speridião PGL, Sdepanian VL, Fagundes Neto U, Morais MB. The performance of parents of children receiving cow's milk free diets at identification of commercial food products with and without cow's milk. J Pediatr (Rio J). 2007;83:459-64. http://dx.doi.org/10.2223/JPED.1697

36. Chong KW, Wright K, Goh A, Meyer R, Rao R. Growth of children with food allergies in Singapore. Asia Pac Allergy. 2018;8:e34. http://dx.doi.org/10.5415/apallergy.2018.8.e34

37. Venter C, Mazzocchi A, Maslin K, Agostoni C. Impact of elimination diets on nutrition and growth in children with multiple food allergies. Curr Opin Allergy Clin Immunol. 2017;3:220-6. http://dx.doi.org/10.1097/ACl.0000000000000358 